Jap. J. Limnol. 44, 2, 81-92, 1983.

\title{
Serological Study on Seasonal and Vertical Distribution of Specific Denitrifying Bacteria in Lake Kizaki*
}

\author{
Hisayoshi TeraI and Takahito YoshiokA
}

\begin{abstract}
Six antisera were prepared against 6 denitrifying bacteria isolated from Lake Kizaki (classified into 2 strains of the Pseudomonas fluorescent group, 2 of the Pseudomonas achromogenic group, 1 of the Pseudomonas group producing no acid and 1 of the Alcaligenes-Achromobacter group).

Using both serological agglutinate reaction and immunofluorescent staining method, 60 isolates and 194 enrichment culture tubes for the MPN estimate of denitrifiers were tested for serological identity with each of the antigen denitrifiers. Fifteen strains among 60 isolates and denitrifiers in 25 tubes among 194 MPN counting tubes were identical to one or another of the 6 antigen denitrifiers. Seasonal and vertical distributions of these 40 identified denitrifying bacteria in the lake were described.

Homologues of two strains of denitrifiers were most frequently found in L. Kizaki $(68 \%$ or 27/40). One of them (Strain B-8, belonging to Pseudomonas fluorescent group) was found only in the circulation period or in the water layer where the dissolved oxygen concentration was about $10 \mathrm{mg} \cdot \mathrm{l}^{-1}$. The other (Strain B-3, belonging to Pseudomonas achromogenic group) was found only in the stratification period or in the water layer where the dissolved oxygen concentration was above $5 \mathrm{mg} \cdot \mathrm{l}^{-1}$.

The fact that both homologues identical to B-3 or B-8 were found in oxic layers suggests that these denitrifiers might grow by aerobic respiration rather than denitrification because of the oxidative nature of their metabolism. However, from the standpoint of denitrifying activity, it is noteworthy that the only exception to the known distribution of these denitrifiers was found in the anoxic hypolimnion in November where many different denitrifiers were found.
\end{abstract}

\section{Introduction}

Denitrification processes have been studied by measuring activities with various techniques in natural environments (e.g., RICHARD and BENSON, 1961; GoERING, 1968; Kolke et al., 1972; SzRENSEN, 1978). In spite of extensive studies on denitrifying activity, ecological studies on denitrifying bacteria are very limited. GAmBle et al. (1977) assumed that numerically dominant organisms isolated were also functionally dominant ones in the natural habitat, and reported numerically dominant denitrifying bacteria from world soils. TERAI (1979) isolated 44 strains of denitrifying bacteria from Lake Kizaki in central Japan, classified them at the generic level, and discussed their seasonal and vertical distribution in relation to the oxygen condition. However,

\footnotetext{
* A preliminary report of a part of this work was pre
} sented at the XXIst SIL Congress in Kyoto, 1980. at the generic level, the relationship between physiological features of denitrifiers, especially those with oxidative activity, and the oxygen condition in their habitat was not clear. To clarify this relationship, studies must be undertaken on the distribution of denitrifying bacteria, at species- or strain- level.

Immunofluorescent staining has been used as a sensitive and useful technique for studying microbial autecology. ScHMIDT (1974) first applied the technique for autecological analysis of Rhizobium and Nitrobacter in soils. Quantitative studies on marine bacteria were thus conducted by ReEd and Dugan (1978) on methylotrophs and WARD and PERRY (1980) on Nitrosococcus oceanus. Recently, DAHLE and LAAKE (1982) applied the technique for the study of the population dynamics of five marine organotrophic bacteria in relation to phytoplankton bloom. 
Table 1. Strains of denitrifying bacteria selected for antigens and designation of homologous antigen and antisera.

\begin{tabular}{|c|c|c|c|}
\hline Taxonomical group & Strain No. & Antigen & Antiserum \\
\hline I Pseudomonas & $6-28-1$ & B 1 & A 1 \\
\hline fluorescent group & $4-0-2$ & B 8 & A 8 \\
\hline II Pseudomonas & $5-10-1$ & B 3 & A 3 \\
\hline achromogenic group & $4-20-2$ & B 7 & A 7 \\
\hline $\begin{array}{l}\text { III Pseudomonas } \\
\text { no acid producing group }\end{array}$ & $6-10-1$ & B 9 & A 9 \\
\hline $\begin{array}{c}\text { IV Alcaligenes-Achromobacter } \\
\text { group }\end{array}$ & $\mathrm{N}-0-1$ & B 2 & A 2 \\
\hline
\end{tabular}

Therefore, application of the immunofluorescent technique for denitrifying bacteria would be expected to obtain useful information for understanding denitrification processes in the natural habitat. In the present study, the authors prepared six antisera against the denitrifying bacteria isolated from Lake Kizaki and attempted to determine the seasonal and vertical distribution of the specific denitrifying bacteria in the lake.

\section{Materials and Methods}

\section{Preparation of antisera}

Six strains of denitrifying bacteria isolated from Lake Kizaki (TERAI, 1979) were selected for antigens and listed in Table 1.

Denitrifying bacteria grown in GiLTAY's medium at $20^{\circ} \mathrm{C}$ were harvested, washed twice with $0.85 \% \mathrm{NaCl}$ solution and finally suspended in phosphate buffer saline (PBS, $\mathrm{pH}$ 7.0) at a concentration of $1 \mathrm{mg}$ dry weight $\cdot \mathrm{m} l^{-1}$. Formaldehyde $(0.5 \%$ final concentration) or merthiolate ( $1 \%$ final concentration) was added for sterilization of the antigens.

This vaccine was stored at $4^{\circ} \mathrm{C}$ during the immunization procedure. Six specific antibodies were produced by the following immunization procedure using 6 rabbits $(3.5-4.0 \mathrm{~kg} \mathrm{wt}): 1.0 \mathrm{ml}$ of the vaccine was injected into the abdominal cavity at intervals of 6 to 7 days; from the 4 th injection, $2.0 \mathrm{ml}$ of the vaccine was injected at an interval of 2 weeks; at 4 to 5 days after the $3 \mathrm{rd}, 4 \mathrm{th}, 5 \mathrm{th}$ and 6 th injection 10 - to $20-\mathrm{m} l$ blood samples were obtained from the marginal vein of the ear. The blood was allowed to coagulate for $1 \mathrm{hr}$ at $37^{\circ} \mathrm{C}$ and stood overnight at $4^{\circ} \mathrm{C}$. Supernatant serum was removed by gentle decantation and the rest by centrifugation $(10,000 \times \mathrm{g}, 30 \mathrm{~min})$. The collected sera were decomplemented by incubation at $56^{\circ} \mathrm{C}$ for $30 \mathrm{~min}$, merthiolate added (final concentration $0.02 \%$ ), and stored at $-20^{\circ} \mathrm{C}$ until use.

Agglutination test and indirect immunofluorescent staining

Antiserum titer was checked by agglutination test with homologous antigen using small glass tubes $(4.5 \mathrm{~mm}$ i. d. and $45 \mathrm{~mm}$ height).

An aliquot $(0.2-0.3 \mathrm{~m} l)$ of the antigen was mixed in the tube with the same volume of antiserum serially diluted by PBS, and incubated at $37^{\circ} \mathrm{C}$ for $1 \mathrm{hr}$ and stood overnight at $4^{\circ} \mathrm{C}$. Agglutinate formation was observed with a loupe of 10 magnification. The result is shown in Table 2.

Table 2. Agglutination titer and used dilution of antisera.

\begin{tabular}{lll}
\hline Antiserum & \multicolumn{1}{c}{ titer } & used dilution \\
\hline A $1^{*}$ & $1: 400-800$ & $\times 100-200$ \\
A 2 & $1: 2,000-4,000$ & $\times 500$ \\
A $3^{*}$ & $1: 400-800$ & x $100-200$ \\
A 7 & $1: 600$ & x 150 \\
A 8 & $1: 2,000$ & $\times 500$ \\
A 9 & $1: 1,200$ & x 300 \\
\hline
\end{tabular}

* non-specific cross reaction was absorbed with B-2. 
Table 3. Mutual cross reactions between prepared antisera and used bacteria for antigens.

\begin{tabular}{ccccccc}
\hline Antigen & \multicolumn{7}{c}{ Antisera } \\
bacteria & A-1 & A-2 & A-3 & A-7 & A-8 & A-9 \\
\hline B-1 & ++ & - & - & - & \pm & - \\
B-2 & - & ++ & - & - & - & - \\
B-3 & - & - & + & - & - & - \\
B-7 & - & - & - & ++ & - & - \\
B-8 & \pm & \pm & \pm & \pm & ++ & \pm \\
B-9 & - & - & - & - & \pm & ++ \\
\hline
\end{tabular}

Mutual cross reactions between, used antigen bacteria and antisera were tested by the same agglutination test and shown in Table 3. Strain B-8 exhibited nonspecific feeble cross reactions, probably because it contained nonspecific antigen, so antisera A-8 sometimes showed a nonspecific ag- glutination reaction.

Cross reactions between prepared antisera and several type strains of denitrifying bacteria were also tested by the same agglutination test and shown in Table 4 . In addition to the above denitrifying bacteria, several heterotrophic bacteria (i.e., Escherichia

Table 4. Test of cross reaction between prepared antisera and type strains of denitrifying bacteria.

\begin{tabular}{|c|c|c|c|c|c|c|}
\hline \multirow{2}{*}{$\begin{array}{l}\text { Tested } \\
\text { bacteria }\end{array}$} & \multicolumn{6}{|c|}{ Antisera } \\
\hline & $A-1$ & A-2 & $A-3$ & A-7 & A-8 & A-9 \\
\hline $\begin{array}{l}\text { Alcaligenes sp. } \\
\text { NCIB } 11015\end{array}$ & - & ++ & - & - & - & - \\
\hline $\begin{array}{l}\text { Al. faecalis } \\
\text { IAM } 1015\end{array}$ & - & - & - & - & - & - \\
\hline $\begin{array}{ll}\text { Ps. } & \text { fuorescens } \\
\text { IFO } 3925 \\
\text { IFO } 12055\end{array}$ & - & - & $\begin{array}{l}- \\
-\end{array}$ & $\begin{array}{l}- \\
-\end{array}$ & $\begin{array}{l}+ \\
+\end{array}$ & - \\
\hline $\begin{array}{l}\text { Ps. aeruginosa } \\
\text { IFO } 3080 \\
\text { IFO } 3755\end{array}$ & - & - & - & - & - & - \\
\hline $\begin{array}{ll}\text { Ps. } & \text { stuzeri } \\
\text { IFO } 12695 \\
\text { IFO } 13596\end{array}$ & $\begin{array}{l} \pm \\
-\end{array}$ & $\begin{array}{l} \pm \\
-\end{array}$ & $\begin{array}{l} \pm \\
-\end{array}$ & $\begin{array}{l} \pm \\
-\end{array}$ & $\begin{array}{l} \pm \\
-\end{array}$ & $\begin{array}{l} \pm \\
-\end{array}$ \\
\hline $\begin{array}{l}\text { Ps. aureofacienc } \\
\text { IFO } 3521\end{array}$ & - & - & - & - & - & - \\
\hline $\begin{array}{l}\text { Ps. azotoformans } \\
\text { IFO } 12693\end{array}$ & - & - & - & - & \pm & - \\
\hline $\begin{array}{l}\text { Ps. chlororaphis } \\
\text { IFO } 3904\end{array}$ & - & - & - & - & - & - \\
\hline $\begin{array}{l}\text { Pa. denitrificans } \\
\text { IFO } 13301\end{array}$ & - & - & - & - & - & - \\
\hline
\end{tabular}


coli, Serratia marcescens, Staphylococcus aureus, and Bacillus subtilis) were tested for agglutination reaction, but none of them showed any cross reaction against any of the prepared antisera. From the result in the table, a clear cross reaction was observed between Alcaligenes sp. (NCIB 11015) and antiserum A-2, of which antigen is a strain classified in AlcaligenesAchromobacter group (see Table 1). Furthermore, antiserum A-8 showed a weak but positive cross reaction against two strains of Pseudomonas fluorescens (IFO 3925 and 12055). The antigen strain of antiserum A-8 is one of the strains classified in the Pseudomonas fluorescent group (Table 1). These results suggest that the serological technique is useful for the detection of a specific species of bacteria in the natural habitat.

Indirect immunofluorescent stainings were performed as follows. Antigens smeared on slide glasses or filtered on Nuclepore filter $(0.4 \mu \mathrm{m}$ pore size) were incubated with antisera at $37^{\circ} \mathrm{C}$ for $1 \mathrm{hr}$ and stood overnight at $4^{\circ} \mathrm{C}$. After washing with PBS, these antisera-combined antigens were incubated with FITC conjugated antirabbit IgG goat IgG (Miles YEDA LTD) diluted 1:50 with $\mathrm{PBS}$ at $37^{\circ} \mathrm{C}$ for $1 \mathrm{hr}$ and stood overnight at $4{ }^{\circ} \mathrm{C}$. After washing with PBS, samples were mounted in immersion oil and viewed with an epifluorescent microscope (Olympus BH-RFL).

Figure 1 shows photomicrographs of indirect immunofluorescent staining. As shown in the figure, brilliant fluorescence and clear shapes of the bacteria, sometimes even stained flagella, were observed in the case of homologous antigen-antisera reaction. On the other hand, weak fluorescence or partial staining which showed irregular shape of the bacteria were observed in the case of non-specific cross reaction.

Bacterial sampling, MPN counting and serological experiment for denitrifying bacteria

Water samples for serological experiments were collected aseptically from Lake Kizaki with an ampoule type sampler (TeraI, (a)

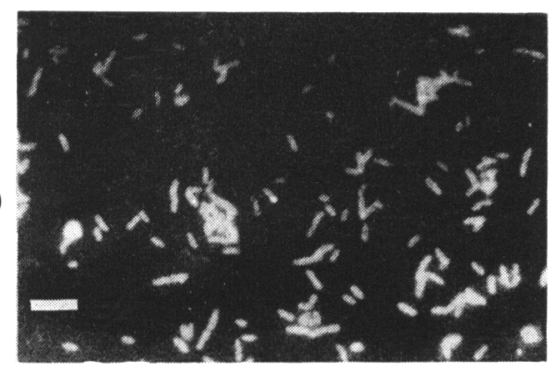

(b)

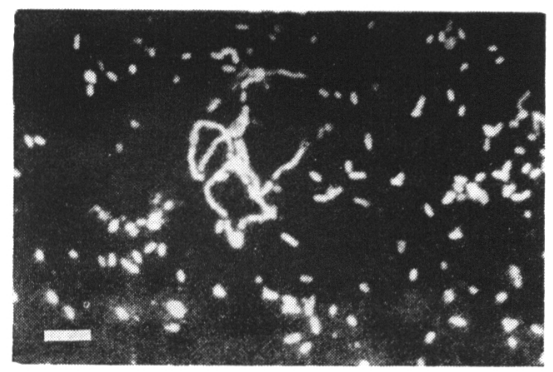

(c)

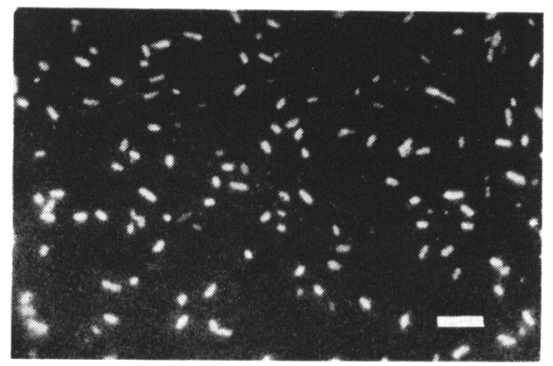

Fig. 1. Photomicrographs of indirect immunofluorescent staining.

(a) Staining of antigen denitrifier B-3 with antisera $\mathrm{A}-3$ and FITC conjugated anti-rabbit IgG goat IgG.

(b) Staining of Alcaligenes sp. ( $\mathrm{NCIB}$ 11015) with antisera A-2 and FITC conjugated anti-rabbit $\operatorname{IgG}$ goat $\operatorname{IgG}$. (c) Staining of denitrifier sampled from NPN-tube which was enriched from surface water of L. Kizaki at 28 July 1980, with antisera A-8 and FITC conjugated anti-rabbit IgG goat IgG. Bars indicate $10 \% \mathrm{~m}$.

1979) on April 11, June 12, July 28, Oct. 7, and Nov. 23 in 1980. MPN counting methods for denitrifying bacteria were employed using $1 / 5$ strength of nutrient broth with $1 \mathrm{~g} \cdot l^{-1} \quad \mathrm{KNO}_{3}$ and 8 tubes in each dilutions except for April (5 tubes in each dilution). After 3 weeks' incubation at $20 \pm 1^{\circ} \mathrm{C}$, denitrifier positive tubes were 
tested for serological cross reaction against each of the prepared antisera. Indirect immunofluorescent staining method was carried out when the specific agglutination reaction was observed. Positive samples both by agglutination reaction and immunofluorescent staining were recognized as indicating the presence of the serologically identical species.

\section{Results}

Identity of denitrifying strains isolated and classified from Lake Kizaki which were tested by serological cross reactions

Forty-four strains of denitrifying bacteria were isolated from Lake Kizaki during 1976-1978 and classified into 5 generic or sub-generic groups (TERAI, 1979). In the present study, 6 strains from 4 groups were selected for antigens: Denitrifying strains were grown in GiLTAY's medium. Forty strains, viable and retaining denitrifying activity, were tested for serological cross reaction against each of the 6 antisera, and the results are shown in Table 5. No cross reaction was found between different taxonomical groups. Strain 8-25-1, which could not have been taxonomically classified into either group III or IV in the previous report, showed a serological identity with

Table 5. Identity of the isoated denitrifying strains from L. Kizaki tested by serological cross reactions.

\begin{tabular}{|c|c|c|c|}
\hline Group I & Group II & Group III & Group IV \\
\hline$-6-28-1 \quad(B-1)$ & $-5-10-1 \quad(B-3)$ & $-6-10-1 \quad(B-9)$ & $-\mathrm{N}-0-1 \quad(\mathrm{~B}-2)$ \\
\hline$-6-28-3$ & $-5-10-2$ & $\cdots(6-10-3)$ & $-\mathrm{N}-0-2$ \\
\hline & $-6-24-2$ & $\cdots(6-10-4)$ & \\
\hline 0-0-1 & & $6-M-1$ & $5-0-1$ \\
\hline $0-5-1$ & O-M-1 & & $5-M-1$ \\
\hline$-\mathrm{N}-10-1$ & $\mathrm{~N}-28-1$ & & \\
\hline & $\mathrm{N}-28-2$ & & -Alcaligenes sp. \\
\hline $4-0-1$ & & & \\
\hline$-4-0-2(B-8)$ & $4-20-1$ & & Group III/IV \\
\hline $4-10-1$ & $\cdots 4-20-2(B-7)$ & & $8-25-1$ \\
\hline$-4-20-3$ & $4-28-1$ & & $0-8-1$ \\
\hline $4-M-1$ & $4-28-2$ & & \\
\hline 4-M-2 & $4-28-3$ & & Group V \\
\hline 4-M-3 & & & $6-20-1$ \\
\hline $4-M-4$ & $8-0-1$ & & $6-24-1$ \\
\hline $4-M-5$ & $\ldots(8-15-1)$ & & \\
\hline$\cdots$ (Ps. fluorescens) & $8-15-2$ & & \\
\hline
\end{tabular}

Designation: Isolated Month-Depth(m)-Numbering

$\mathrm{O}$ : October, $\mathrm{N}$ : November, $\mathrm{M}$ : mud.

-: Identical strains confirmed both by agglutination

- test and by fluorescent antibody staining.

‥: Strains exhibited weak reaction by agglutination

... test but negative by fluorescent antibody technique. 
B-9. Thus, strain 8-25-1 should be classified into Group III. Strain B-7 has no identical strain except for strain 8-15-1, the positive reaction of which could not be confirmed by the immunofluorescent staining. Each of strain B-1 and B-2 has an identical strain isolated from the same water sample. Both B-3 and B-8 show the presence of an identical strain isolated from a different water sample.

Serological identification of isolated but not classified denitrifying strains from Lake Kizaki

Twenty strains of denitrifying bacteria were isolated and purified from Lake Kizaki in July 1978. For these strains, which were not classified taxonomically, the serological cross reaction was tested using 6 antisera in the same way as for classified strains. Three among 20 strains were found to be identical to B-3.

MPN counting tubes, which exhibited the presence of denitrifying bacteria, had been kept at $4^{\circ} \mathrm{C}$ for several months. Among 24 and 17 tubes thus kept from June and August 1979, respectively, 8 and 13 tubes were found to retain viability and denitrifying activity, respectively. With the enrichment culture of the denitrifier, the serological cross reaction was tested against 6 antisera. The denitrifier in one tube originating from June sample was identical to strain $\mathrm{B}-3$, and one among 13 tubes from August sample showed a serological identity to strain B-2.

Seasonal change in vertical distribution of denitrifiers in Lake Kizaki from April to November in 1980

Vertical distribution of denitrifiers in Lake Kizaki during 1976-1978 was studied by the MPN counting method (TERAI, 1979). The medium of the MPN estimate for denitrifiers was revised to $1 / 5$ strength of nutrient broth with $1 \mathrm{~g} \cdot l^{-1} \quad \mathrm{KNO}_{3}$, because this medium showed more positive reactions than GiLTAY's medium in the MPN tubes of higher lake water dilutions. Except for April, 8 tubes-MPN in each dilution were used and a more dense $(4 \mathrm{~m}$ interval) sampling was performed in 1980 , in order to obtain not only more accurate MPN estimate but more positive samples.

On April 11, the lake water was still in the spring overturn phase except for the uppermost layers, as seen in the vertical profiles of water temperature and dissolved oxygen (Fig. 2a). It was found earlier that denitrifying bacteria as well as total heterotrophic bacteria (in viable counts) were distributed homogeneously throughout the water column during the circulating period of lake water (TERAI, 1979). In 1980, as shown in Fig. 2a, denitrifying bacteria were distributed almost homogeneously throughout the water column in the range of $1-10 \mathrm{cells} \cdot \mathrm{m} l^{-1}$, the same range observed in 1977.

From June to October, the lake water was in the summer stratification phase. Denitrifying bacteria as well as total heterotrophs were previously found to be distributed heterogeneously in the water column; moreover, the layers in which denitrifying bacteria were not detected (ND layer), were present in the stratification period (TERAI, 1979). In 1980, the $\mathrm{ND}$ layer was found only at $12 \mathrm{~m}$ depth in October (Fig. 2d). As shown in Fig. $2 \mathrm{~b}-\mathrm{d}$, the layers with a very low denitrifier density in the stratification period of 1980 $(0,8,12$ and $16 \mathrm{~m}$ depth in June; 8, $12 \mathrm{~m}$ depth in July; and $12,20 \mathrm{~m}$ depth in October) were very close to the ND layers found in the early study $(0,15$, and $20 \mathrm{~m}$ depth in June; $10 \mathrm{~m}$ depth in July; and 15, $20 \mathrm{~m}$ depth in November as reported by TeraI, 1979).

As shown in Fig. 2e, on November 23, when water circulation reached the middle layer of the lake, the denitrifier distribution seemed to be homogeneous in the circulating layer $\left(1.6-2.6\right.$ cells $\cdot \mathrm{m}^{-1}$ in $0-12 \mathrm{~m}$ depth) and a dense denitrifier population $\left(20\right.$ cells $\left.\cdot \mathrm{m}^{-1}\right)$ was found in the bottom anoxic layers (24 and $28 \mathrm{~m}$ depth).

From these results, it is reconfirmed that distribution of denitrifiers in the lake was homogeneous in the circulating period and heterogeneous or discontinuous with very low density (or with ND layers) in 

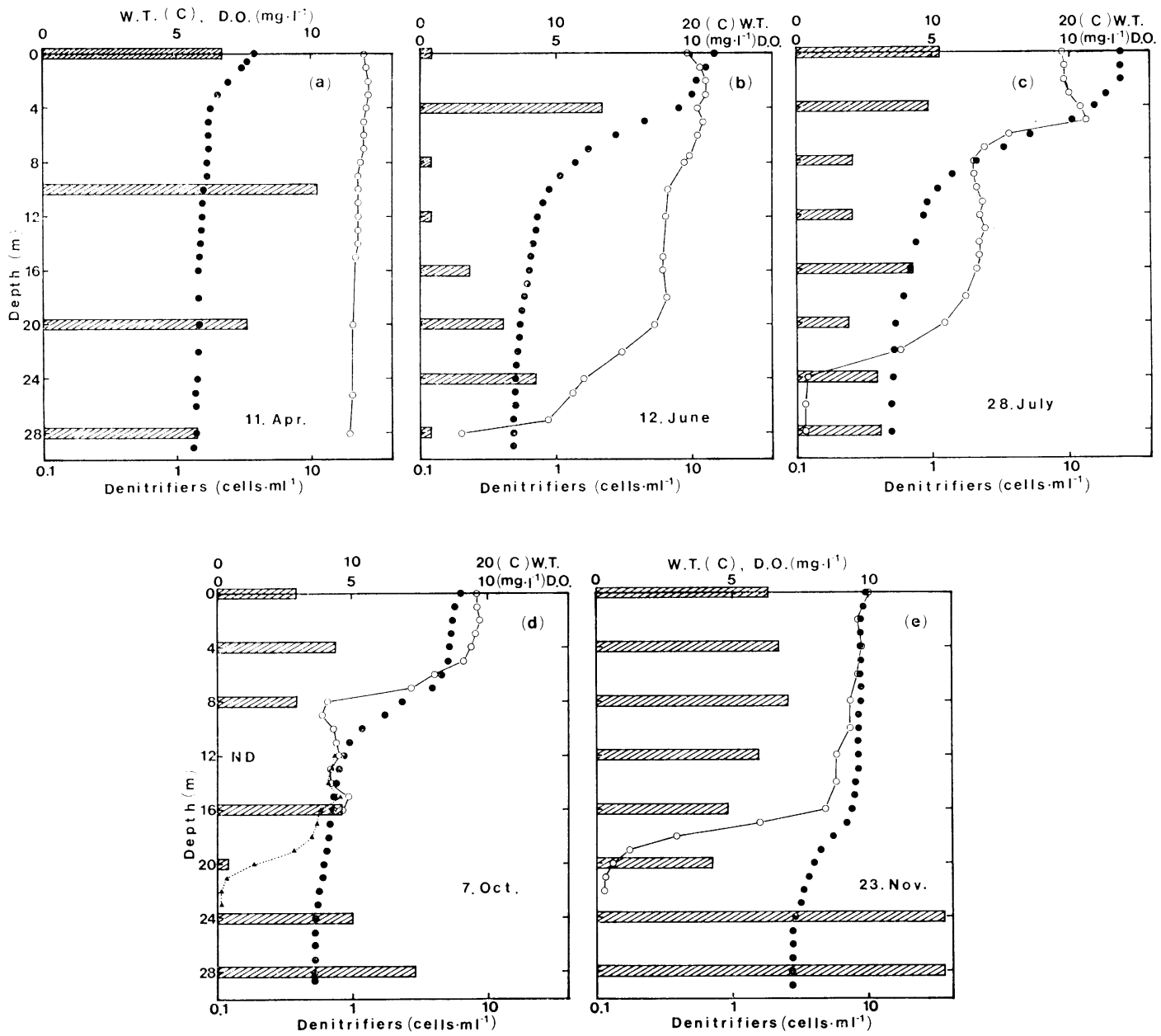

Fig. 2. Vertical distributions of denitrifying bacteria in Lake Kizaki.

Closed circle: water temperature; open circle with solid line: dissolved oxygen measured by oxygen meter (YSI-57); hatched column: numbers of denitrifying bacteria estimated by MPN method in $1 / 5$ strength of nutrient broth with $1 \mathrm{~g} \cdot l^{-1}$ $\mathrm{KNO}_{3}$ added; ND: not detected.

(a) 11 April, (b) 12 June, (c) 28 July, (d) 7 October, (e) 23 November, in 1980. In the case of 7 October, oxygen data were not obtained below $16 \mathrm{~m}$ depth, so that reference data obtained at 11 October in 1981 were plotted below $12 \mathrm{~m}$ depth (solid triangle with dotted line).

the stratification period.

Detection of specific denitrifying bacteria in MPN positive tubes from April to November in 1980

From April to October, during the course of MPN estimation, positive tubes were preserved at $4^{\circ} \mathrm{C}$ when they were found at every 2- or 3-day observation. After final observation (3 weeks), denitrifiers pre- served in each positive tube were reinoculated into fresh medium. Samples for serological testing were obtained from the 2nd enrichment. Table 6 shows the result of serological cross reaction on 94 denitrifier positive tubes sampled from April to October. It is clear in the table that identical denitrifiers as B-3 are found most frequently during the summer stratification 
Table 6. Detection of specific denitrifying bacteria in the positive tubes of MPN estimate.

\begin{tabular}{lccccc}
\hline \multicolumn{1}{c}{ Month } & / April & June & July & October & Total \\
\hline $\begin{array}{l}\text { No. of denitrifying } \\
\text { tubes in MPN estimate }\end{array}$ & 27 & 23 & 29 & 34 & 113 \\
$\begin{array}{l}\text { No. of viable denitrifying } \\
\text { tubes in reinoculation }\end{array}$ & 19 & 23 & 29 & 23 & 94 \\
$\begin{array}{l}\text { No. of serologically } \\
\text { positive cross reaction }\end{array}$ & 1 & 3 & $2+2$ & 1 & 9 \\
\begin{tabular}{l} 
(identified strain) \\
\hline
\end{tabular} & (B-8) & (B-3) & $(B-3$, B-8) & (B-9) & \\
\hline
\end{tabular}

Table 7. Distribution of specific denitrifiers in L. Kizaki on Nov. 23, 1980 identified by serological cross reactions.

\begin{tabular}{cccccccc}
\hline Depth/Strain & B-1 & B-2 & B-3 & B-7 & B-8 & B-9 & Total/Tested \\
\hline $0 \mathrm{~m}$ & 0 & 0 & 0 & 0 & 1 & 0 & $1 / 8$ \\
$4 \mathrm{~m}$ & 0 & 0 & 0 & 0 & 2 & 0 & $2 / 9$ \\
$8 \mathrm{~m}$ & 0 & 0 & 0 & 0 & 3 & 0 & $3 / 10$ \\
$12 \mathrm{~m}$ & 0 & 0 & 1 & 0 & 1 & 0 & $2 / 9$ \\
$16 \mathrm{~m}$ & 1 & 0 & 0 & 0 & 0 & 0 & $1 / 6$ \\
$20 \mathrm{~m}$ & 0 & 0 & 0 & 0 & 0 & 0 & $0 / 5$ \\
$24 \mathrm{~m}$ & 0 & 0 & 0 & 2 & 0 & 0 & $2 / 16$ \\
$28 \mathrm{~m}$ & 1 & 0 & 1 & 0 & 1 & 0 & $3 / 16$ \\
Total & 2 & 0 & 2 & 2 & 8 & 0 & $14 / 79$ \\
Non-denitrifying & - & - & 0 & 0 & 0 & - & $0 / 30$ \\
NO-reducer & & & & & &
\end{tabular}

period in the lake. Identical denitrifier to B-8 was found in the circulating period, and those detected in July were found only in the samples originating from the surface layer.

In November, direct sampling from denitrifier positive tubes and testing of serological reaction were carried out at weekly intervals during the course of the MPN estimation. Table 7 shows the serological identification for 79 denitrifier positive tubes in the MPN estimate of November sample.

In the course of this MPN estimation, $\mathrm{NO}_{3}^{-}$-reducing but nondenitrifying bacteria $\left(\mathrm{NO}_{2}^{-}\right.$-accumulator) were found in 30 tubes ( 1 tube at $0 \mathrm{~m}$ and $8 \mathrm{~m}, 2$ tubes at $4 \mathrm{~m}, 4$ tubes at $12 \mathrm{~m}$ and $20 \mathrm{~m}$, and 6 tubes at $16 \mathrm{~m}, 24 \mathrm{~m}$ and $28 \mathrm{~m}$ ). Serological cross reactions were also tested on these $\mathrm{NO}_{3}^{-}$- reducers against 3 antisera (A-3, A-7 and A-8). The result was also shown in Table 7. No serological cross reaction was found in any tubes containing nondenitrifying $\mathrm{NO}_{3}^{-}$-reducers, demonstrating the validity of serological identification for distinguishing specific denitrifying bacteria from nondenitrifying types.

From the results shown in the table, denitrifiers in 14 tubes among 79 denitrifier positive tubes (about 18\%) exhibited serological identity as either of strain B-1, B-3, B-7 or B-8. Many serological cross reactions against antisera A-8 (8 tubes, 10\%) were observed. In November (Fig. 2e) denitrifying bacteria were distributed homogeneously in the layer of water circulation $(0-12 \mathrm{~m})$. This finding is very consistent with that of the serological experiment, since denitrifiers serologically identical to B-8 were noted in every layer of the water 
circulation $(0-12 \mathrm{~m})$. At $8 \mathrm{~m}$ depth, where 3 cross reactions were found against antisera A-8 among 10 tested tubes and the MPN estimate for denitrifier was 2.6 cells $\cdot \mathrm{m} l^{-1}$, the MPN for B- 8 was calculated from the number of positive cross reactions and estimated to be 0.4 cells $\cdot \mathrm{m} l^{-1}$.

It is noteworthy that serological cross reactions were more diverse in the lowest 2 layers $(24,28 \mathrm{~m})$ near the bottom, where cross reactions against 4 antisera were found except for A-2 and A-9.

Qualitative estimate of seasonal and vertical distribution of specific denitrifying bacteria in Lake Kizaki

With serological cross reaction against 6 antisera applied to 60 isolated strains and to 194 denitrifiers positive tubes in MPN estiamtion, 15 (including 6 antigen denitrifiers) and 25 denitrifiers serologically identical to one or another of the 6 antigen denitrifiers were exhibited, respectively. The seasonal and vertical distribution of these 40 denitrifiers serologically identified in the lake where they originated is shown in Fig. 3.

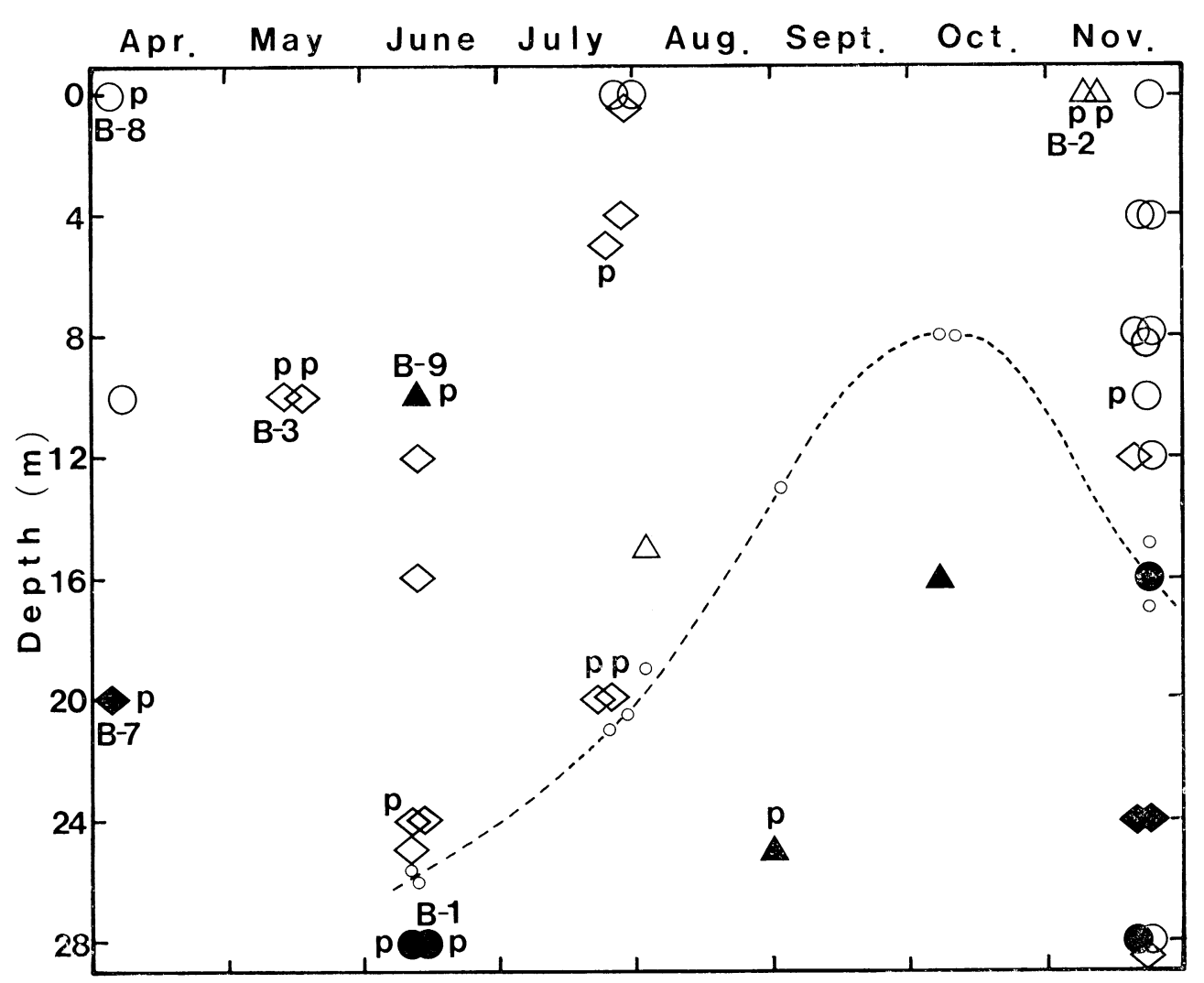

Fig. 3. Qualitative estimate of seasonal and vertical distribution of 6 specific denitrifying bacteria in Lake Kizaki by serological study.

Serologically identified denitrifiers of 15 isolated strains and of 25 MPN tubes were plotted at their originated habitat in L. Kizaki.

$\bigcirc, \diamond, \diamond, \diamond, \triangle, \Delta: \mathrm{B}-8, \mathrm{~B}-1, \mathrm{~B}-3, \mathrm{~B}-7, \mathrm{~B}-2, \mathrm{~B}-9$, and their homologues, respectively; $\mathrm{p}$ : identified denitrifier from isolated and purified strain; $\mathrm{B}-1, \mathrm{~B}-2$, B-3, B-7, B-8, B-9: originated habitat of each antigen strain; Open circle with dotted line: contour line of $5 \mathrm{mg} \cdot \mathrm{l}^{-1}$ dissolved oxygen plotted from the data of 12 June, 28 July, 7 October, 23 November in 1980 and 10 June, 2 August, 23 November in 1979 and 24 July, 2 September, 11 October in 1978. 
It is clear that two strains of denitrifying bacteria (B-3 and $\mathrm{B}-8$ ) belonging to Pseudomonas were the most frequent in Lake Kizaki among the 6 denitrifying strains under study. Sixty-eight per cent (or 27 of 40 serologically identified) of the denitrifiers were identical either to B-3 or B-8. Furthermore, it is interesting that these two strains of denitrifier seem to be distributed differently in a lake. Denitrifiers B-8 and its homologue were found only in the circulating period (April and November) except for the topmost surface layer in July. On the other hand, denitrifier B-3 and its homologue were mainly found in the stratification period (May to July), although exceptions were found at $12 \mathrm{~m}$ and $28 \mathrm{~m}$ in November.

\section{Discussion}

INGRAHAM (1981) compiled 63 denitrifying species in 26 genera, more than half of which were not described in the 8th edition of BERGEY's Manual (1974) but found to denitrify in the decade of 1970's. In spite of such accumulation of taxonomical knowledge on denitrifying bacteria, their ecological study in the natural habitat was limited only to a static description of the presence or abundance of some denitrifying species in a certain habitat.

GAMBLE et al. (1977) isolated 146 denitrifying strains from 19 world-wide soils (including sediments) and classified them into 10 species groups by numerical taxonomy. Half of the isolates were classified into main 2 species groups (53 strains into Pseudomonas fluorescens biotype II, and 21 strains into Pseudomonas sp. - Alcaligenes sp.). NAKAJIMA (1982) isolated 53 denitrifying bacteria from freshwater environments and classified them into 5 genera. Two-thirds of them (35 strains) were Pseudomonas.

In spite of these extensive studies, the dynamics of certain species or genera of denitrifiers corresponding environmental factors such as oxygen content, have not been yet clarified.

TERAI (1979) classified 44 denitrifying isolates from Lake Kizaki into 5 generic or subgeneric groups and reported dominant distribution of 2 Pseudomonas groups (Pseudomonas fluorescent group and Pseudomonas achromogenic group), especially in the water circulating period. However, statistical treatment did not succeed in finding a certain correlation between distribution of these pseudomonads and dissolved oxygen.

In the present study, the serological technique was used to identify homologous species of denitrifying bacteria in the isolated strains and then applied to detect their presence in enrichment cultures during the MPN estimate for denitrifiers. From the present results, it is clear that homologues of 2 different species of Pseudomonas were most frequently found in the lake, and that one of them (B-8, Pseudomonas fluorescent group) was found mainly in the circulating period, in contrast with that the other (B-3, Pseudomonas achromogenic group), which was found predominantly in the summer stratification period.

In the period of water circulation, dissolved oxygen contents, were around 10 $\mathrm{mg} \cdot \mathrm{l}^{-1}$. And even in the case that homologues of B-8 were found in the surface layer of the summer stratification period, dissolved oxygen content was also about $10 \mathrm{mg} \cdot l^{-1}$. On the other hand, although B-3 and its homologues were found in the summer stratification period, in the water layer where they were originated, dissolved oxygen contents were above $5 \mathrm{mg} \cdot l^{-1}$. As for these two dominant denitrifiers in Lake Kizaki, their distribution is very reasonable in relation to the dissolved oxygen concentration, since Irzuk a and Komagata (1963) reported higher oxidative activities with Pseudomonas spp. in the fluorescent group than in other groups. Pseudomonas spp. in the achromogenic group is still oxidative (oxidative feature in $\mathrm{HuGH}$ LEIFSON's OF test), so their distribution is still restricted in oxic layers even in the stratification period.

However, only one exception in the distribution of these two pseudomonads was 
found in November at $28 \mathrm{~m}$ depth where oxygen was depleted less than 0.1-0.2 $\mathrm{mg} \cdot l^{-1}$. On the other hand, as previously mentioned, the presence of a large number of denitrifier $\left(20 \mathrm{cells} \cdot \mathrm{m} l^{-1}\right)$ was shown in MPN estimation, and the diversity of denitrifying species was suggested by the serological cross reaction (3 different denitrifiers in $28 \mathrm{~m}$ depth and another one in $24 \mathrm{~m}$ depth were found among 6 strains tested). These facts indicate that at the anoxic bottom layers of the lake, environmental conditions are favorable for active denitrification, by which every denitrifiers might grow there.

All denitrifiers are aerobes except for a Propionibacterium sp. which is a true fermentative anaerobe. So distribution of denitrifying bacteria does not always correspond to denitrifying activity, especially in the oxic environment. Moreover, denitrification in an oxic environment still remains to be elucidated, either by the presence of anaerobic sites in microstructure (JANNASCH, 1960) or by the presence of true aerobic (MEIKLEJOHN, 1940) or oxygen-tolerant (TERAI, 1979) denitrification. Thus, physiological features of each denitrifier, especially with oxidative activity, is most important in discussing the relationship between distribution and activity of denitrifiers in the natural habitat.

GAMBLE et al. (1977) assumed that numerically dominant organisms isolated were also functionally dominant ones in the natural habitat. However, in the results of the present study, two pseudomonads most frequently found in Lake Kizaki would not likely be functional in denitrification, except for the case of anoxic environment at $28 \mathrm{~m}$ depth in November, by reason of the higher dissolved oxygen contents where they were found and their higher oxidative property as discussed in TERAI (1979).

Probable denitrifiers functional in Lake Kizaki would be those such as B-2 or B-9, which were found either in the oxic or anoxic layer; their denitrifying activities seems to be tolerant for oxygen (TERAI, 1979). But unfortunately, in the present study, their distributions were not found frequently. More data about their distribution or use of antisera against other strains belonging to the same group would give further information about functionally dominant denitrifiers in Lake Kizaki.

YosHIOKA et al. (1982 a, b) established a direct counting method in mixed culture system of nitrifying bacteria using an immunofluorescent technique. Application of such direct counting method to the quantitative estimation of denitrifiers in natural habitat would yield more useful information to clarify the contributions of each denitrifying species to in situ denitrification.

This work was supported in part by a Grantin-Aid for Scientific Research (No. 464208) from the Ministry of Education, Science and Culture.

\section{摘 要}

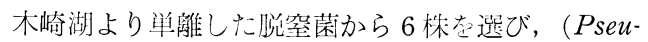
domonas fluorescent group 2 株: B-1, B-8; Pseudomonas achromogenic group 2 株: B-3, B-7; Pseudomonas no acid producing group 1 株: B-9 ; Alcaligenes-Achromobacter group 1 株: B-2) 6 種の抗血清を諴製した。特異的凝集反応および間接 螢光抗体法を用いて，木崎湖より単離した脱㖕菌 60 株について，6種の抗原脱窒菌との血清学的同一性を 調べた結果，15菌株（6抗原菌株を含む）が同定され た。また MPN 法により木崎湖における脱空菌数の 鉛宜分有の季節変化を胃るとともに，脱窒菌の存在が 確認された 194 本の MPN-tube について上記抗原菌 株との同一性を検定した。 その結果，25本について 6 種抗原菌のいずれかと血清学的同一州が確涩された。

この中で, Pseudomonas fluorescent group に病 する B-8 と Pseudomonas achromogenic group に 属する B-3 の 2 菌株との同一性株法全体 の 689 (27/40) 卆占め, 調べた 6 菌株の中では最も優占し た。また血清学的に问走された 15 菌株および 25 本の MPN-tube について, それぞれの起源試水との刘応 関係から，木崎测における 6 種脱空菌の㸴節的・鉛直 的分有学見た。 その結果，最も優占した 2 箱株 B-3 および B-8 との同一性株は明らかに異なる分行夌小 した。すなわち，B-8 同一性株は 4 月，11月の湖水 の唒環期または浴存酸素濃度 $10 \mathrm{mg} \cdot l^{-1}$ 前後の極》 て好気们な水層にのみ分们し，乙れに刘して B-3 问 一性株は 6 ～8月の湖水の成層期または溶你訟素瀑度 $5 \mathrm{mg} \cdot l^{-1}$ 以上のやや好気的な水層にのみ分行した。

これら 2 菌株との同一性株力゙とに好気水嘚に見出 されたここは，乙れらの䒩株グループの酸化的な代衙

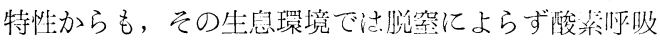
により增列灰行なっているてと存示すものと将えられ

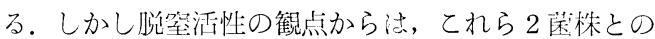


同一性株の分布の唯一の例外が娧気的な11月の深水層 に見られ，またその場の脱窒菌が数 $\left(20 \mathrm{cells} \cdot \mathrm{m} l^{-1}\right)$, 種類ともに多く見出されたととが注目される。

\section{References}

Buchanan, R.E. and N.E. Gibbons (eds.) (1974): Bergey's Manual of Determinative Bacteriology, 8th ed., Williams \& Wilkins.

Dahle, A. B. and M. LaAke (1982): Diversity dynamics of marine bacteria studied by immunofluorescent staining on membrane filters. Appl. Environ. Microbiol., 43: 169-176.

Gamble, T. N., M. R. Betlach and J. M. Tiedje (1977) : Numerically dominant denitrifying bacteria from world soils. Appl. Environ. Microbiol., 33: 926-939.

Goering, J. J. (1968) : Denitrification in the oxygen minimum layer of the Eastern Tropical Pacific Ocean. Deep-Sea Res., 15: 157-164.

IizukA, H. and K. Komagata (1963) : Taxonomy of genus Pseudomonas with special reference to their modes of metabolism of carbon compound. J. Gen. Appl. Microbiol., 9: 83-95.

Ingraham, J. L. (1981) : Microbiology and genetics of denitrifiers. In: C.C. Delwiche (ed.), Denitrification, nitrification, and atmospheric nitrous oxide. John Wiley \& Sons.

Jannasch, H. W. (1960) : Versuche über Denitrifikation und die Verfügbarkeit des Sauerstoffes in Wasser und Schlamm. Arch. Hydrobiol., 56: 355-369.

Koike, I., E. Wada, T. Tsuji and A. Hattori (1972) : Studies on denitrification in a brackish lake. Arch. Hydrobiol., 69: 508-520.

Meiklejohn, J. (1940): Aerobic denitrification. Ann. Appl. Biol., 27: 558-573.

Nakajima, T. (1982): Distribution of denitrifying bacteria and its controlling factors in freshwater environments. Jap. J. Limnol., 43: $17-26$.

Reed, W. M. and P. R. Dugan (1978) : Distribu- tion of Methylomonas methanica and $\mathrm{Me}$ thylosinus trichosporium in Cleveland harbor as determined by an indirect fluorescent antibody-membrane filter technique. Appl. Environ. Microbiol., 35: 422-430.

Richard, F. A. and B. B. Benson (1961): Nitrogen/argon and nitrogen isotope ratios in two anaerobic environments, the Cariaco Trench in the Caribbean Sea and Dramsfjord, Norway. Deep-Sea Res., 7: 254-264.

Schmidt, E. L. (1974) : Quantitative autecological study of microorganisms in soil by immunofluorescence. Soil. Sci., 118: 141-149.

Sørensen, J. (1978): Denitrification rates in marine sediments as measured by the acetylene inhibition technique. Appl. Environ. Microbiol., 36: 139-143.

Terai, H. (1979) : Taxonomic study and distribution of denitrifying bacteria in Lake Kizaki. Jap. J. Limnol., 40: 81-92.

Ward, B. B. and M. J. Perry (1980): An immunofluorescent assay for the marine ammonium-oxidizing bacterium Nitrosococcus oceanus. Appl. Environ. Microbiol., 39: 913-918.

Yoshioka, T., H. Terai and Y. Saijo (1982 a) : Growth kinetic studies of nitrifying bacteria by the immunofluorescent counting method. J. Gen. Appl. Microbiol., 28: 169-180.

Yoshioka, T., H. Terai and Y. Saijo (1982 b) : Analysis of the growth of $\mathrm{NH}_{4}^{+}$-oxidizing bacteria and $\mathrm{NO}_{2}^{-}$-oxidizing bacteria in mixed culture. J. Gen. Appl. Microbiol., 28: 181-188.

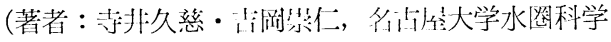
研究所, 公古屋市千種区不老町; Hisayoshi TerAI, Takahito Yosніока, Water Research Institute, Nagoya University, Chikusa-ku, Nagoya 464)

Accepted: 6 November 1982 